FOREWORD Special Issue 'Biological control of tree and woody plant diseases'

\title{
Biological control of tree and woody plant diseases: an impossible task?
}

Francisco M. Cazorla ${ }^{1}$, Jesús Mercado-Blanco ${ }^{2 *}$

${ }^{1}$ Instituto de Hortofruticultura Subtropical y Mediterránea 'La Mayora', IHSM-UMACSIC, Dpto. Microbiología, Facultad de Ciencias, Universidad de Málaga, Campus Universitario de Teatinos s/n, E-29071 Málaga, Spain; and ${ }^{2}$ Departmento de Protección de Cultivos, Instituto Agricultura Sostenible, Agencia Estatal Consejo Superior de Investigaciones Científicas (CSIC), Avda. Menéndez Pidal s/n, Campus Alameda del Obispo s/n, E-14004 Córdoba, Spain.

\footnotetext{
* Author for correspondence: Dr. Jesús Mercado-Blanco, Departamento de Protección de Cultivos, Instituto Agricultura Sostenible, Agencia Estatal Consejo Superior de Investigaciones Científicas (CSIC), Avda. Menéndez Pidal s/n, Campus Alameda del Obispo s/n, E-14004 Córdoba, Spain.

Email: jesus.mercado@ias.csic.es
} 
Francisco M. Cazorla is associate professor in the Department of Microbiology, Faculty of Science, Málaga University (Institute for Mediterranean and Subtropical Horticulture "La Mayora", IHSM-UMA-CSIC). His main research on microbial plantmicrobe interactions is related with the elucidation of the multitrophic interactions that take place on the roots during the biocontrol, using as a model the subtropical avocado tree. Special attention is paid to the bacterial genus Pseudomonas and Bacillus and its molecular bases of acting against soil borne phytopathogenic fungi.

Jesús Mercado-Blanco is tenured scientist in the Institute for Sustainable Agriculture (Spanish National Research Council, CSIC). His main research interests focus on agricultural microbiology and biotechnology and the development of control tools within integrated disease management strategies, using Verticillium wilt of olive as study model. Specific research topics are the bases underlying plant-microbe interactions by molecular and '-omic' approaches and the identification, characterization and use of microbiological control agents, with emphasis on bacterial endophytes. 


\section{$1 \quad$ Biological control of tree and woody plant diseases: an impossible task?}

2

\section{Abstract}

4

5 The social demand for novel, sustainable and environment friendly approaches, while 6 ensuring the health and productivity of our crops, is increasingly growing. Research on

7 biological control of tree/woody crop diseases is scarce compared to that conducted on

8 herbaceous, annual plants. In addition to their large biomass, complicated anatomy,

9 longevity and perennial nature, peculiarities in the management of tree crops and

10 forestry also contribute to the complexity of the processes of developing effective

11 biological control measures in these agro-ecosystems. Although biological control in

12 woody species poses challenges, difficulties and limitations, its implementation either

13 alone or in combination with other disease management strategies is feasible. As a

14 result, examples of successful application of biocontrol measures based on the use of 15 bacteria, fungi or hypovirulent mycoviruses against tree/woody plant diseases are 16 available. The aim of this Special Issue is to provide interested readers with an overview 17 and updates on the active research field of biological control of tree and woody plant diseases. Such effort includes updates ranging from the generation of fundamental knowledge to examples of successful application of biological control strategies. endophyte, guava (Psidium guajava L.), grapevine (Vitis vinifera L.), microbiome, 24 Verticillium wilt of olive (Olea europaea L.) 
Trees and woody crops are crucial for life on Earth. In fact, forests and other wooded lands cover about $40 \%$ of the world's land surface (FAO 2010). Crowther and coworkers (2015) have recently estimated that the global number of forest trees is approximately 3.04 trillion, exceeding previous estimates by far and stressing the magnitude of this massive biomass. Besides forests, huge acreages of agricultural soils are devoted to the cultivation of a large variety of trees and woody plants worldwide (e.g. Camellia sinensis (L.) Kuntze, Citrus spp., Coffea spp., Malus domestica B., Olea europea L., Phoenix dactylifera L., Persea americana Mill., Prunus spp., Theobroma cacao L., Vitis vinifera L., etc.). Domestication and cultivation of woody species is part of the human history and these commodities became essential to the economy of many countries. Extraction of non-timber products from the forest may be considered as the initial phase of domestication of valuable tree species (Prance 1994). Thus, the first woody plants to be cultivated were those yielding food and other non-timber products, such as olive, edible fig and grapes (around 4,000 BC) in the Mediterranean area, or diverse fruit trees (around 2,000 BC) in Asia (Turnbull 2002). Over the centuries, these activities have shaped particular landscapes, generating outstanding agro-ecosystems in many regions around the world. Trees and woody plants do not only provide edible products essential for human and animal diets, but also important goods (e.g., wood,

47 paper, etc.). Moreover, they play key roles in nutrient and water cycling processes, 48 preventing soil erosion, mitigating the effects of climate change acting as carbon dioxide sink, and supporting microbial, animal and plant biodiversity (Ruano-Rosa and Mercado-Blanco 2015). The health of forests and woody cropping systems is therefore

51 of particular relevance. However, a range of biotic constraints due to the attacks of a 
52 diversity of viruses, phytoplasms, bacteria, oomycetes, fungi, nematodes, arthropods

53 and parasitic plants continuously compromise the fitness, development and production

54 of trees and woody plants (Fig. 1). For instance, many soil-borne phytopathogens provoke serious losses in economically-relevant tree crops and forestry. Among them, different species of fungi (e.g. Fusarium, Armillaria, Heterobasidion, Rosellinia, Verticillium, etc.) and oomycetes (e.g. Phytophthora, Pythium, etc.) genera (GarcíaJiménez et al. 2010), and pathogenic bacteria such as Agrobacterium tumefaciens (de Cleene and de Ley 1976) are particularly harmful and may cause great losses. Additionally, many foliar pathogens provoke severe diseases on woody plants, such as fungal-based powdery mildew or cankers (Agrios 2005; Amano 1986; Manion 1991), or the aggressive aerial phytopathogenic bacteria Erwinia amylovora (causing fire blight; Vanneste 2000) and Pseudomonas syringae (causing bacterial blights; Kennelly et al. 2007). To complete the catalogue of important pathogenic organisms causing relevant diseases on tree and woody plants, we must not forget pathogenic viruses (Cooper 1979) and nematodes (Ruehle 1973).

New emergent diseases are gaining relevance worldwide (Santini et al. 2013). These are usually characterized by the presence of severe symptoms, whose control is challenging. Diseases such as the citrus Huanglongbing (previously known as "citrus greening”, and caused by different “Candidatus Liberibacter spp.”; Wang and Trivedi 2013), the oak decline (caused by the oomycete Phytophthora cinnamomi; CamiloAlves et al. 2013) or the olive quick decline (caused by the bacterium Xylella fastidiosa; Martelli et al. 2016) are catching the interest of nearly all society and pose new and urgent research challenges. Finally, it is worth mentioning that the development of new cultivation systems (Connor et al. 2014) or either sudden or long-term changes in weather/climate conditions (Ponti et al. 2014) can have an as yet poorly-understood 
77 influence on woody crop diseases, as well as unknown effects on the effectiveness of 78 the disease management strategies traditionally deployed to contain them. These scenarios warrant future in-depth studies that, in our opinion, should be conducted based on a holistic perspective involving multidisciplinary research teams together.

82 Challenges in biocontrol of tree and woody plant diseases

84 Plant diseases are one of the main limiting factors in modern agriculture, holding potential for a devastating effect on plant health and yield. In addition to agronomic and cultural practices, growers are usually forced to resort to the use of chemical treatments. However, growing public concern about environmental pollution and harmful effects of chemicals in humans and animals, are paving the way for searching new, more environment friendly disease control methods. Mitigation strategies are effective only in some areas, and solutions to woody plant diseases and pests mainly focus on integrating different management approaches. Within this global strategy, biological control is considered as an interesting complement to other management practices. However, the different facets of this scenario have so far been rather poorly explored. been investigated in a number of pathosystems involving woody hosts (Milgroom and Cortesi 2004; Pliego and Cazorla 2012, and references therein). Nevertheless, a survey

97 in the scientific literature reveals that, overall, the utilization of BCAs as a disease 98 control strategy has been implemented to a lesser extent in trees and woody plants 99 compared to that in herbaceous species, annual crops and seedlings. A number of reasons could explain the lower implementation and/or success of biological control approaches in trees and woody plants. These may include challenges that have not been 
102 encountered so far, or that are not as easily overcome when dealing with annual crops.

103 Factors such as a larger biomass, a more complex anatomy, a greater longevity, the 104 perennial nature, and/or inherent particularities in the management of tree crops and 105 forests (e.g. absence of crop rotation aiming to reduce the pathogen inoculum level, 106 etc.), make it more difficult to develop and implement effective biological control 107 approaches. For instance, in the case of soil-borne pathogens, the large root systems of 108 trees and their architecture may facilitate repeated infection events from any given 109 pathogen persisting in soils as dormant, quiescent or resistant propagules (e.g. 110 chlamydospores, microsclerotia, etc.). Moreover, infection episodes can take place 111 either in the same season or in successive ones. This fact may contribute to reduce the 112 effectiveness of biocontrol strategies (Pliego and Cazorla 2012). In other cases, such as

113 for vascular pathogens, a tree can only be partially affected by the disease during a 114 growing season. The syndrome is not thus leading to the death of the entire plant but to 115 severe symptoms of individual branches, thereby limiting or stopping tree growth and 116 production. This may pose difficulties when making a decision on which type of disease 117 managing strategy is more appropriate to implement. For instance, López-Escudero and 118 Mercado-Blanco (2011) have highlighted the complexity to control Verticillium dahliae 119 in olive (Olea europaea) due to, among other factors, the pathogen's location within the 120 vascular vessels, a tissue difficult to be reached either by chemical or biological 121 treatments. Another example is found in Burr et al. (1998) who reported that attempts to 122 control crown gall disease, caused by A. tumefaciens have largely failed, except by 123 using the biological control bacterium Agrobacterium radiobacter K84 (New and Kerr 124 1972). However, biocontrol cross-protection is restricted to only certain Agrobacterium 125 strains; so these approaches face limitations when they need to be implemented (Anand 126 et al. 2008). In other cases, propagules of pathogens infecting woody hosts (e.g. 
127 Uncinula necator causing powdery mildew in grapevine [Vitis vinifera], Rosellina

128 necatrix causing white root rot on avocado [Persea Americana], or Venturia inequalis 129 causing apple [Malus domestica] scab) overwinter either on plant debris or plant

130 organs/tissues (Pearson and Gadoury 1987; Holb et al. 2004; Pliego et al. 2012; Melnick

131 et al. 2013), making the application of effective control measures difficult. Finally, olive

132 knot caused by the bacterial pathogen Pseudomonas savastanoi pv. savastanoi (Ramos

133 et al. 2012) can be considered as a model for woody plant diseases in which the causal

134 agent is constantly present in plant tissues. Interestingly, the use of the biocontrol root

135 endophyte Pseudomonas fluorescens PICF7 resulted in a reduction of necrotic tumors

136 and confinement of the pathogen at inner regions of the knots, although disease

137 development was not impaired (Maldonado-Gómez et al. 2013).

139 Biocontrol approaches for woody plant diseases

141 In spite of these difficulties, a range of biocontrol-based measures have been developed

142 and are practicable for woody plants. So far, however, they mostly focus on the seedling 143 phase, young plants and/or during the nursery propagation stage (Mercado-Blanco et al. 144 2004; Abraham et al. 2013; González-Sánchez et al. 2013; Vitullo et al. 2013). The 145 question ahead yet to be asked when implementing biocontrol strategies for woody 146 plants, either alone or in combination with other disease management approaches, is

147 whether they can be consistently and effectively used with adult individuals, under field 148 conditions, and on large scales (orchards, forests, etc.). One more relevant question to 149 be addressed is whether the use of biological control measures is feasible from an 150 economical perspective, considering the idiosyncrasy of tree and woody agro151 ecosystems. For instance, deep root systems usually developed by trees are less 
152 accessible to chemical- or physical-based disease management approaches, thereby

153 reducing their effectiveness (López-Herrera et al. 2003). It is conceivable to think that

154 deep soil layers will be also less accessible to biologically-based control approaches

155 (e.g. deploying formulations harboring biocontrol agents by irrigation).

156 Biocontrol approaches to confront tree and woody plants diseases are diverse,

157 encompassing strategies such as the use of hypovirulent viruses and fungi (El Hassni et

158 al. 2004; Milgroom and Cortesi 2004), beneficial bacteria and/or their secondary

159 metabolites to control, for instance, bayoud disease (Fusarium oxysporum f. sp.

160 albedinis) in date palm (Phoenix dactylifera) (El Hassni et al. 2007) or diverse

161 grapevine pathogens (Compant et al. 2012, and references therein), fungi displaying a

162 multiplicity of biocontrol mechanisms such as Trichoderma spp. against avocado

163 (Persea americana) white root rot (Ruano-Rosa and López-Herrera 2009) or

164 Phlebiopsis gigantea against the root and butt rot disease of conifers caused by

165 Heterobasidion annosum (Mgbeahuruike et al. 2011; 2012), and organic amendments

166 with antagonistic microorganisms (Moreira et al. 2007) which in addition can stimulate

167 soil-resident beneficial microbiota (Bonilla et al. 2015). Thus, the use of organic

168 amendments or mulches has been successfully incorporated into integrated management

169 of certain diseases, such as those affecting avocado trees (Pérez-Jiménez 2008; Bonilla

170 et al. 2012). This is mainly due to the fact that avocado roots are easily accessible since

171 they are mostly in the upper centimeters of the soil $(60 \%$ of the roots in the first $60 \mathrm{~cm}$

172 of the soil; Salazar-Garcia and Cortés-Flores 1986). An interesting and promising

173 approach, although insufficiently explored, is the use of endophytic microorganisms

174 (Hardoim et al. 2015). Beneficial bacteria and fungi showing effective biocontrol

175 activity and displaying endophytic lifestyle offer the advantage to be adapted and to

176 endure within plant tissues for long periods of time, conferring them great potential in 
177 agricultural biotechnology (Mercado-Blanco and Lugtenberg 2014). Adaptation to inner

178 tissues and endurance within them make endophytes good candidates as biocontrol 179 agents of long-living, woody plant diseases. Indeed, tree endophytes have been

180 proposed as an excellent tool aiming to sustain forest health (Pautasso et al. 2015).

181 Examples of effective and/or promising use of bacterial endophytes to control diseases

182 in trees are already available, such as in olive against the soil-borne vascular pathogen

183 V. dahliae (Maldonado-González et al. 2015), against poplar (Populus spp.) canker 184 caused by Cytospora chrysosperma, Phomopsis macrospora and Fusicoccum aesculi

185 (Ren et al. 2013), diverse cacao (Theobroma cacao) pod diseases (Melnick et al. 2011), 186 or against Xylella fastidiosa sbsp. pauca causing citrus variegated chlorosis (CVC)

187 disease of sweet oranges (Citrus sinensis L) (Lacava et al. 2004; 2007). Noteworthy, 188 this pathosystem poses an additional interest. Indeed, the vector of CVC, the 189 sharpshooter insect Bucephalogonia xanthophys, also transports the endophytic 190 biocontrol bacterium Methylobacterium mesophilicum (Gai et al. 2009). This offers

191 stimulating perspectives to develop innovative biocontrol approaches for this pathogen.

192 Overall, while some results have been obtained using endophytes in different 193 pathosystems under controlled conditions, yet the actual challenge is to develop 194 appropriate strategies for their formulation, application and efficient use in woody agro195 ecosystems and forestry.

197 Aim and content of this Special Issue

199 In this volume, several examples of on-going research on biocontrol approaches in 200 different pathosystems involving trees and woody plants are presented (Fig. 1). They 201 confirm that even though challenges and difficulties are encountered when confronting 202 woody plant diseases by biocontrol approaches, fundamental knowledge is 
203 progressively gathered and promising results are obtained. Moreover, successful 204 application of biocontrol measures is a reality in some cases.

205 Microbiomes of plants have a strong impact on their health, growth and 206 productivity. Likewise, several factors influence the abundance, diversity and 207 composition of the plant-associated microbial communities. The complexity of the plant 208 microbiome is not yet fully understood, and several attempts to unravel its influence on 209 the host have been performed in different crops of interest, such as grapevine (Pinto et 210 al. 2014; Zarraonaindia et al. 2015). In this Special Issue, two studies deal with different 211 aspects of biocontrol in grapevine. Pinto and Gomes (2016) review how basic research

212 on grapevine microbiome could lead to new technological developments to improve 213 agriculture productivity and sustainability. This can be achieved by exploiting 214 microorganisms harboring beneficial traits for the plant, identifying new genes and enzymes with potential to be used in novel strategies for crop protection. In this work, it is proposed that the knowledge gathered about the plant-associated microbiome can

217 assist in the elucidation of plant-microbial interactions taking place, thus revealing 218 microorganisms that could be involved in plant protection processes. By this basic 219 knowledge, and facing a possible disease scenario, different microbial-based tools could 220 be developed thanks to the previous research performed on the plant microbiome. Pertot 221 and coworkers (2016) present one of the few works focused on the promising use of the 222 well-known biocontrol agent Trichoderma spp. during the grapevine nursery process.

223 Phaeoacremonium aleophilum and Phaeomoniella chlamydospora are pathogens

224 commonly associated with wood discoloration symptoms in tracheomycotic syndromes 225 of esca, and are thus considered the causal agents of this phaeotracheomycotic complex.

226 Infections commonly occur in vineyards or derive from infected mother plants.

227 However, the grafting process in nurseries can also pose an additional risk of infection. 
The analysis of different Trichoderma spp. biocontrol agents applied during this special

229 stage of the plant revealed that although new approaches to reduce the risk of fungal

230 pathogen infection in nurseries can been proposed, the preventive use of strain SC1 of

231 Trichoderma atroviridae could be a feasible and relatively cheap control measure.

Verticillium wilt is one of the most threatening biotic constrains for olive

233 cultivation in many areas where this tree is cultivated. So far, the best approach to

234 confront the disease is by implementing an integrated disease management strategy

235 (López-Escudero and Mercado-Blanco 2011), in which biological control measures can

236 play a role, mainly when applied in a preventive way. In this Special Issue, three studies

237 devoted to the biocontrol of this disease are included. Ruano-Rosa and co-workers

238 (2016) describe in detail the behavior of Trichoderma harzianum, a widely-used BCA,

239 once released in the olive rhizosphere. Using a fluorescently-labeled derivative of $T$.

240 harzianum CECT 2413 and confocal laser scanning microscopy, they observed for the

241 first time events related to mycoparasitism of $V$. dahliae by $T$. harzianum in vitro.

242 Moreover, they found that most of the biomass of CECT 2413 was mainly visualized as

243 chlamydospores, a resistant structure, soon after being released in the olive rhizosphere,

244 regardless of the experimental conditions used and the absence or presence of the

245 pathogen. This observation suggests that this BCA seems not to be able to persist in a

246 metabolically-active form when applied as a spore suspension, raising interesting

247 questions about the way this BCA should be formulated and deployed to reach full

248 effectiveness. In another study, Markakis and associates (2016) evaluated the biocontrol

249 efficiency of the bacterium Paenibacillus alvei, strain K165, against the same pathogen

250 under both greenhouse and field experimental conditions. While bioassays conducted in

251 greenhouse revealed that strain K165 significantly decreased disease development in a

252 susceptible olive cultivar, a major step forward of this study was to confirm the 
suppressive effect of K165 in an established olive orchard naturally infested with $V$.

254 dahliae. Among other interesting observations, this study reports for the first time 255 effective biological control of this disease under field conditions, a scenario not

256 frequently explored in biocontrol research, particularly with woody plants. Finally, Varo

257 and coworkers (2016) compared diverse pathogen inoculation methods to screen for

258 potential biocontrol agents against $V$. dahliae in olive, addressing one of the major

259 restrictions when developing control measures against this disease: the lack of

260 consistent inoculation methods to evaluate, for instance, the effectiveness of biocontrol

261 agents. The authors eventually propose a promising inoculation method to assess

262 potentially effective BCAs against Verticillium wilt of olive, an important step before

263 evaluation under field conditions.

264 Dutch elm (Ulmus spp.) disease, caused by species of the fungal genus 265 Ophiostoma, is a devastating disease affecting elms in Europe and North America.

266 Infections mostly occur by pathogen transmission by several species of bark beetles,

267 mainly from the genus Scolytus, although infection by means of root contact between

268 infected and healthy trees can also take place. Biological control of Dutch elm disease

269 under field conditions has already a long history (Scheffer et al. 2008). In this issue,

270 Postma and Goossen-van de Geijn (2016) report on the successful use of a biological

271 control approach to protect a tree over a long period of time ( $>20$ years) and under

272 natural (and urban) conditions. Moreover, this is an interesting case on the use of a

273 pathogenic fungus (Verticillium albo-atrum strain WCS850) behaving as a protective

274 agent in a non-host species. While the product under study does not protect already-

275 infected elm trees or trees connected with diseased individuals via root grafts, it does

276 prevent healthy trees from pathogen infection through elm bark beetles. 
278 bark lesions on the stem and branches of chestnut (Castanea spp.), developing chestnut

279 blight (Prospero and Rigling 2013). The consequences of this disease are less dramatic

280 in Europe on the European chestnut (Castanea sativa Mill.) than in North America on

281 the American chestnut (Castanea dentata (Marshall) Borkh.) due, among other factors,

282 to the spontaneous appearance and spread of natural hypovirulence caused by an

283 unencapsidated RNA virus (Heiniger and Rigling 1994). This made chestnut blight as

284 one of the few tree diseases in Europe for which biological control is possible. In this

285 Special Issue, Prospero and Rigling (2016) revealed that therapeutic canker treatment

286 with a virus is mostly effective. However, Cryphonectria virus could yield contradictory

287 results, due to competition with naturally-occurring viruses. This study also emphasizes

288 the usefulness of molecular markers to track biological control agents and to evaluate

289 the success of their application.

290 Another hot topic in biological control of trees and woody plants are the pests

291 which severely affect plant performance and yield. Even though this volume is focused

292 on diseases, we also aimed to include an example illustrating biocontrol strategies

293 implemented to manage tree pests. One study model is the common guava (Psidium

294 guajava L.), where different insect pests can be found, such as the fruit fly (Bactrocera

295 spp.), the fruit borer (Deudorix Isocrates Fab,) or different types of Lepidoptera,

296 Hemiptera and Homoptera (Souza et al. 2003). Management of insect pests involves

297 several applications of chemicals, mainly targeting the adult form. To avoid the

298 environmental concerns caused by the effects of pesticides, alternative measures are

299 being developed, including those based on biological control. Dolinski (2016) presents

300 in this Special Issue a review on how natural pathogens of insects, such as the

301 entomopathogenic nematodes, often play an important role in regulating insect pest 
302 populations, and proposes them as components of Integrated Pest Management (IPM) 303 programs.

304 Another model to study biocontrol on woody plants is the citrus phytopathogenic 305 nematode Tylenchulus semipenetrans, which causes heavy attacks on young feeder 306 citrus roots. Moreover, its pathogenicity can be enhanced by stress related to soil and/or 307 water availability (Duncan and Noling 1987). In this issue, Ciancio and co-workers 308 (2016) confirm the potential of the bacterium Pasteuria spp. to effectively control the 309 citrus nematode. Moreover, by modeling obtained data, a clear relationship between $T$. 310 semipenetrans and Pasteuria sp. is shown, making it possible to have a management 311 strategy of this nematode based on the use of this bacterium.

\section{Concluding remarks}

315 Research conducted on biological control of woody plant diseases, including the examples compiled here are stimulating and encourage further research in all aspects

317 related to the use of biological control in these agro-ecosystems, particularly as a 318 preventive measure. Moreover, biocontrol approaches, or more particularly the use of 319 BCAs, can be complementary to other disease control measures (e.g. the use of 320 pathogen-free certified planting material, the use of tolerant/resistant cultivars, their 321 combined use with organic amendments, etc.) and/or integrated with appropriate 322 agronomical or forestry practices. Nevertheless, our knowledge on the mechanisms 323 underlying biocontrol, on the influence of environmental factors on the effectiveness of 324 BCAs, on the interaction between a given BCA and the plant-associated microbiome 325 once the former is released in the target host, on the colonization ability of the BCA, or 326 on how the plant respond to the presence of the BCA, are still scant. The 
327 implementation of currently-available, powerful '-omic' technologies will definitively

328 boost our understanding on woody plant-BCA-pathogen interactions (Massart et al.

329 2015). So far, these approaches have been used in trees and woody plants to a lesser

330 extent than in herbaceous species, although examples are increasingly available (Sun et

331 al. 2011; Palmieri et al. 2012; Mgbeahuruike et al. 2013; Gómez-Lama Cabanás et al.

332 2014; Calderón et al. 2015; Martínez-García et al. 2015), and many more will be on

333 hand soon. Likewise, proper understanding of the causes behind inconsistencies

334 observed with BCAs is urgent, particularly when they are released under field

335 conditions and a multiplicity of (a)biotic factors is dynamically interacting. Working

336 with trees and woody plants, and considering the peculiarities of these plants which

337 have been briefly described above, can accentuate these inconsistencies. In spite of

338 these difficulties, the use of biocontrol measures, either alone or complementary to other

339 actions within IPM frameworks, is feasible and should have a promising future as

340 sustainable and environmental-friendly approaches.

341 Finally, we would like to express our sincere gratitude to all researchers who

342 collaborated by submitting their latest results in the field of biological control of tree

343 and woody plant diseases. Their works demonstrate that the biocontrol of tree and

344 woody plant diseases is not an impossible task. We are also in debt to Dr. Eric

345 Wajnberg for his continuous encouragement and enthusiasm to make this Special Issue 346 a reality.

\section{$348 \quad$ References}


350 Abraham A, Philip S, Jacob SK, Jayachandran K (2013) Novel bacteria endophytes from Hevea brasiliensis as biocontrol agent against Phytophthora leaf fall disease. BioControl 58:675-684

Agrios GN (2005) Plant Pathology, 5th ed. Elsevier, Academic Press, New York. 922 p.

Amano K (1986) Host range and geographical distribution of the powdery mildew fungi. Tokyo: Japan Scientific Societies Press. 741 p.

Anand A, Uppalapati SR, Ryu C-M, Allen SN, Kang L, Tang Y, Mysore KS (2008) Salicylic acid and systemic acquired resistance play a role in attenuating crown gall disease caused by Agrobacterium tumefaciens. Plant Physiol 146:703-715

Blakeman JP, Fokkema NJ (1982) Potential for biological control of plant diseases on the phylloplane. Ann Rev Phytopathol 20:167-190.

Bonilla N, Gutiérrez-Barranquero JA, de Vicente A, Cazorla FM (2012) Enhancing soil quality and plant health through suppressive organic amendments. Diversity $4: 475-491$

Bonilla N, Vida C, Martínez-Alonso M, Landa BB, Gaju N, Cazorla FM, de Vicente A (2015) Organic amendments to avocado crops induce suppressiveness and influence the composition and activity of soil microbial communities. Appl Environ Microbiol 81:3405-3418

Burr TJ, Otten L (1999) Crown gall of grape: biology disease management. Anny Rev Phytopathol 37:53-80

Calderón CE, Ramos C, de Vicente A, Cazorla FM (2015) Comparative genomic analysis of Pseudomonas chlororaphis PCL1606 reveals new insight into antifungal compounds involved in biocontrol. Mol Plant-Microbe Interact 28:249-260 
374 Camilo-Alves CDEP, Esteves da Clara MI, Cabral de Almeida Ribeiro NM (2013) Decline of Mediterranean oak trees and its association with Phytophthora cinnamomi: a review. Eur J For Res 132:411-432

Ciancio A, Roccuzzo G, Ornat Longaron C (2016) Regulation of the citrus nematode Tylenchulus semipenetrans by a Pasteuria sp. endoparasite in a naturally infested soil. BioControl (this issue) DOI: 10.1007/s10526-015-9704-1

380 de Cleene M, de Ley J (1976) The host range of Crown gall. Bot Rev 42:388-466

381 Compant S, Brader G, Muzammil S, Sessitsch A, Lebrihi A, Mathieu F (2012) Use of 382 beneficial bacteria and their secondary metabolites to control grapevine pathogen diseases. BioControl 58:435-455

Connor DJ, Gomez del Campo M, Rousseaux MC, Searles PS (2014) Structure, management and productivity of hedgerow olive orchards: A review. Sci Hort 169:71-93

Cooper JI (1979) Virus diseases of trees and shrubs. Institute of Terrestrial Biology, Cambridge, p 74

Crowther TW, Glick HB, Covey KR, Bettigole C, Maynard DS, Thomas SM, Smith JR, Hintler G, Duguid MC, Amatulli G, Tuanmu MN, Jetz W, Salas C, Stam C, Piotto D, Tavani R, Green S, Bruce G, Williams SJ, Wiser SK, Huber MO,

Dolinski C (2016) Entomopathogenic nematodes against the main guava insect pests. BioControl (this issue) DOI: 10.1007/s10526-015-9695-y 
Duncan LW, Noling JW (1987) The relationship between development of the citrus root system and infestation by Tylenchulus semipenetrans. Revue Nématol 10:61-66

El Hassni M, El Hadrami A, Daayf F, Cherif M, Barka EA, El Hadrami I (2007) Biological control of Bayoud disease in date palm: Selection of microorganisms inhibiting the causal agent and inducing defense reactions. Environ Exp Bot

El Hassni M, J'Aiti F, Dihazi A, Ait Barka E, Daayf F, El Hadrami I (2004) Enhancement of defence responses against Bayoud disease by treatment of date palm seedlings with an hypoaggressive Fusarium oxysporum isolate. J Phytopathol 152:182-189

Food and Agriculture Organization of the United Nations (2010) Global forest resources http://foris.fao.org/static/data/fra2010/FRA2010GlobaltablesEnJune29.xls.

Gai C, Lacava P, Quecine M, Auriac M-C, Lopes J, Araújo W, Miller T, Azevedo J

García-Jiménez J, Monte E, Trapero A (2010) Los hongos y oomicetos fitopatógenos. In: Jiménez Díaz R, Montesinos Segui E (eds) Enfermedades de las plantas causadas por hongos y oomicetos. Naturaleza y control integrado, Phytoma, España, pp 23-50 (in Spanish) The biocontrol endophytic bacterium Pseudomonas fluorescens PICF7 induces systemic defense responses in aerial tissues upon colonization of olive roots. Front Microbiol 5:427 
González-Sánchez MA, de Vicente A, Pérez-García A, Pérez-Jiménez R, Romero D, Cazorla FM (2013) Evaluation of the effectiveness of biocontrol bacteria against avocado white root rot occurring under commercial greenhouse plant production conditions. Biol Control 67:94-100

Hardoim PR, van Overbeek LS, Berg G, Pirttilä AM, Compant S, Campisano A, Döring M, Sessitsch A (2015) The hidden world within plants: ecological and evolutionary considerations for defining functioning of microbial endophytes. Microbiol Mol Biol Rev 79:293-320

Heiniger U, Rigling D (1994) Biological control of chestnut blight in Europe. Annu Rev Phytopathol 32:581-599

Holb IJ, Heijne B, Jeger MJ (2004) Overwintering of conidia of Venturia inaequalis and the contribution to early epidemics of apple scab. Plant Dis 88:751-757

Kennelly MM. Cazorla FM, de Vicente A, Ramos C, Sundin GW (2007) Pseudomonas syringae diseases of fruit trees - Progress toward understanding and control. Plant Dis 91:4-17

Lacava PT, Araújo WL, Marcon J, Maccheroni W, Azevedo JL (2004) Interaction between endophytic bacteria from citrus plants and the phytopathogenic bacteria Xylella fastidiosa, causal agent of citrus-variegated chlorosis. Lett Appl Microbiol 39:55-59

Lacava P, Li W, Araújo W, Azevedo J, Hartung J (2007) The endophyte Curtobacterium flaccumfaciens reduces symptoms caused by Xylella fastidiosa in Catharanthus roseus. J Microbiol 45:388-393

López-Escudero FJ, Mercado-Blanco J (2011) Verticillium wilt of olive: a case study to implement an integrated strategy to control a soil-borne pathogen. Plant Soil $344: 1-50$ 
López-Herrera CJ, Perez-Jiménez RM, Basallote-Ureba MJ, Zea Bonilla T, MeleroVara JM (2003) Effect of soil solarization on the control of Phytophthora root rot in avocado. Plant Pathol 46:329-340

Maldonado-González MM, Prieto P, Ramos C, Mercado-Blanco J (2013) From the root to the stem: interactions between the biocontrol root endophyte Pseudomonas fluorescens PICF7 and the pathogen Pseudomonas savastanoi NCPPB 3335 in olive knots. Microbial Biotechnol 6:275-287

Maldonado-González MM, Schilirò E, Prieto P, Mercado-Blanco J (2015) Endophytic colonization and biocontrol performance of Pseudomonas fluorescens PICF7 in olive (Olea europaea L.) are determined neither by pyoverdine production nor swimming motility. Environ Microbiol 17:3139-3153

Manion PD (1991) Tree disease concepts, 2nd ed. Prentice-Hall, Englewood Cliffs, NJ, $402 \mathrm{p}$.

Markakis EA, Sotirios ET, Antoniou PP, Paplomatas EJ, Tjamos EC (2016) Biological control of Verticillium wilt of olive by Paenibacillus alvei, strain K165. BioControl (this issue) DOI: 10.1007/s10526-015-9669-0

Martelli GP, Boscia D, Porcelli F, Saponari M (2016) The olive quick decline syndrome in south-east Italy: a threatening phytosanitary emergency. Eur J Plant Pathol $144: 235-243$

Martínez-García P, Ruano-Rosa D, Schilirò E, Prieto P, Ramos C, RodríguezPalenzuela P, Mercado-Blanco J (2015) Complete genome sequence of Pseudomonas fluorescens strain PICF7, an indigenous root endophyte from olive (Olea europaea L.) and effective biocontrol agent against Verticillium dahliae. Stand Genomic Sci 10:10 
Massart S, Perazzolli M, Höfte M, Pertot I, Jijakli MH (2015) Impact of the omic technologies for understanding the modes of action of biological control agents against plant pathogens. BioControl 60:725-746

Melnick RL, Bailey BA, Backman PA (2013) Bacterial Endophytes of Perennial Crops for Management of Plant Disease. In: Maheshwari DK (ed) Bacteria in Agrobiology: Disease Management, Springer-Verlag, Berlin Heidelberg, pp 4976

Melnick RL, Suárez C, Bailey BA, Backman PA (2011) Isolation of endophytic endosporeforming bacteria from Theobroma cacao as potential biological control agents of cacao diseases. Biol Control 57:236-245

Mercado-Blanco J, Rodríguez-Jurado D, Hervás A, Jiménez-Díaz RM (2004) Suppression of Verticillium wilt in olive planting stocks by root-associated fluorescent Pseudomonas spp. Biol Control 30:474-486

Mercado-Blanco J, Lugtenberg B J J (2014). Biotechnological applications of bacterial endophytes. Curr Biotechnol 3: 60-75

Mgbeahuruike AC, Karlsson M, Asiegbu FO (2012) Differential expression of two hydrophobin genes (Pgh1 and Pgh2) from the biological control agent Phlebiopsis gigantean. Fungal Biol 116: 620-629

Mgbeahuruike AC, Kohler A, Asiegbu FO (2013) Expression analysis of the impact of culture filtrates from the biocontrol agent, Phlebiopsis gigantea on the conifer aathogen, Heterobasidion annosum s.s. transcriptome. Microb Ecol 66: 669-681

Mgbeahuruike AC, Sun H, Fransson P, Kasanen R, Daniel G, Karlsson M, Asiegbu FO (2011) Screening of Phlebiopsis gigantea isolates for traits associated with biocontrol of the conifer pathogen Heterobasidion annosum. Biol Control 57: $118-129$ 
Milgroom MG, Cortesi P (2004) Biological control of chestnut blight with hypovirulence: a critical analysis. Annu Rev Phytopathol 42:311-338

Moreira AC, Domingos AC, Fontes AM, Semedo J, Melo E, Machado H, Reis M, Horta M, Cravador A (2007) Evaluation of cork and holm oak seedling viability to Phytophthora cinnamomi infection treated with compost and mycorrhizae fungi.

New PB, Kerr A (1972) Biological control of crown gall: field measurements and glasshouse experiments. J Appl Bacteriol 35:279-287.

Palmieri MC, Perazzolli M, Matafora V, Moretto M, Bachi A, Pertot I (2012) Proteomic analysis of grapevine resistance induced by Trichoderma harzianum T39 reveals specific defence pathways activated against downy mildew. J Exp Bot 63:6237-

Pautasso M, Schlegel M, Holdenrieder O (2015) Forest health in a changing world. Microb Ecol 69:826-842

Pearson RC, Gadoury DM (1987) Cleistothecia, the source of primary inoculum for grape powdery mildew in New York. Phytopathology 77:1509-1514

Pérez-Jiménez RM (2008) Significant avocado diseases caused by fungi and oomycetes. Eur J Plant Sci Biotechnol 2:1-24

Pertot I, Prodorutti D, Colombini A, Pasini L (2016) Trichoderma atroviride SC1 prevents Phaeomoniella chlamydospora and Phaeoacremonium aleophilum infection of grapevine plants during the grafting process in nurseries. BioControl

519 Pinto C, Gomez AC (2016) Vitis vinifera microbiome: from basic research to technological development. BioControl (this issue) DOI: 10.1007/s10526-016$9725-4$ 
522 Pinto C, Pinho D, Sousa S, Pinheiro M, Egas C, Gomes AC (2014) Unravelling the diversity of grapevine microbiome. PLoS ONE 9:e85622

Pliego C, Cazorla FM (2012) Biocontrol of tree root diseases. In: Bruijn FJ (ed) Molecular microbial ecology of the rhizosphere, vol 2. Wiley Blackwell, New Jersey, pp 655-663

Pliego C, López-Herrera C, Ramos C, Cazorla FM (2012) Developing tools to unravel the biological secrets of Rosellinia necatrix, an emergent threat to woody crops. Mol Plant Pathol 13:226-239

Ponti L, Gutierrez AP, Ruti PM, Dell'Aquila A (2014) Fine-scale ecological and economic assessment of climate change on olive in the Mediterranean Basin reveals winners and losers. Proc Natl Acad Sci USA 111:5598-5603

Postma J, Goossen-van de Geijn H (2016) Twenty-four years of Dutch Trig® application to control Dutch Elm Disease. BioControl (this issue) DOI: $10.1007 / \mathrm{s} 10526-016-9731-6$

Prance GT (1994) Amazonian tree diversity and the potential for supply of non-timber forest products. In: Leakey RRB, Newton AC (eds), Tropical trees: the potential

Prospero S, Rigling D (2013) Chestnut Blight. In: Gonthier P, Nicolotti G (eds), Infectious Forest Diseases, CAB International, Wallingford, UK, pp 318-339

Prospero S, Rigling D (2016) Using molecular markers to assess the establishment and spread of a mycovirus applied as a biological control agent against chestnut blight. BioControl (this issue) DOI: 10.1007/s10526-015-9713-0 pv. savastanoi: some like it knot. Mol Plant Pathol 13:998-1009 
547 Ren JH, Li H, Wang YF, Ye JR, Yan AQ, Wu XQ (2013) Biocontrol potential of an endophytic Bacillus pumilus JK-SX001 against poplar canker. Biol Control $67: 421-430$

Ruano-Rosa D, López-Herrera CJ (2009) Evaluation of Trichoderma spp. as biocontrol agents against avocado white root rot. Biol Control 51:66-71

Ruano-Rosa D, Mercado-Blanco J (2015) Combining biocontrol agents and organics amendments to manage soil-borne phytopathogens. In: Meghvansi MK, Varma A (eds), Organic Amendments and Soil Suppressiveness in Plant Disease Management, Soil Biology 46, Springer International Publishing, Switzerland, pp 457-478

Ruano-Rosa D, Prieto P, Rincón AM, Gómez-Rodríguez MV, Valderrama R, Barroso JB, Mercado-Blanco J (2016) Fate of Trichoderma harzianum in the olive rhizosphere: time course of the root colonization process and interaction with the

Ruehle JL (1973) Nematodes and forest trees - types of damage to tree roots. Ann Rev Phytopathol 11:99-118

Salazar-Garcia S, Cortés-Flores JI (1986) Root distribution of mature avocado trees

Santini A, Ghelardini L, De Pace C, Desprez-Loustau ML, Capretti P, Chandelier A, Cech T, Chira D, Diamandis S, Gaitniekis T, Hantula J, Holdenrieder O, Jankovsky L, Jung T, Jurc D, Kirisits T, Kunca A, Lygis V, Malecka M, Marcais growing in soils of different textures. California Avocado Soc Yearbook 70:165174

B, Schmitz S, Schumacher J, Solheim H, Solla A, Szabo I, Tsopelas P, Vannini A, Vettraino AM, Webber J, Woodward S, Stenlid J (2013) Biogeographical 
patterns and determinants of invasion by forest pathogens in Europe. New Phytol 197:238-250

574

575

576

577

578

579

580

581

582

583

584

585

586

587

588

589

590

591

592

593

594

595

Scheffer RJ, Voeten JGWF, Guries RP (2008) Biological control of Dutch elm disease. Plant Disease 92:192-200

Souza JC, Haga A, Souza MA (2003) Pragas da goiabeira. Tech Bull no. 71, 60 pp.

Sun H, Paulin L, Alatalo E, Asiegbu FO (2011) Response of living tissues of Pinus sylvestris to the saprotrophic fungus Phlebiopsis gigantea. Tree Physiol 31:438451

Turnbull JW (2002) Tree domestication and the history of plantations. In: Squires VR (ed) The role of food, agriculture, forestry and fisheries in human nutrition Vol. II. Encyclopedia of Life Support Systems developed under auspices of UNESCO. EOLSS Publishers, Oxford, UK, pp 48-74

Vanneste JL (2000) Fire Blight: the disease and its causative agent, Erwinia amylovora. CAB International, Wallingford, UK, $375 \mathrm{p}$

Varo A, Moral J, Lozano-Tóvar MD, Trapero A (2016) Development and validation of an inoculation method to assess the efficacy of biological treatments against Verticillium wilt in olive trees. BioControl (this issue) DOI: $10.1007 / \mathrm{s} 10526-$ $015-9710-3$

Vitullo D, Altieri R, Esposito A, Nigro F, Ferrara M, Alfano G, Ranalli G, De Cicco V, Lima G (2013) Suppressive biomasses and antagonist bacteria for an ecocompatible control of Verticillium dahliae on nursery-grown olive plants. Int $\mathbf{J}$ Environ Sci Technol 10:209-220

Wang N, Trivedi P (2013) Citrus Huanglongbing: A newly relevant disease presents unprecedented challenges. Phytopathology 103:652-665 
596 Zarraonaindia I, Owens SM, Weisenhorn P, West K, Hampton-Marcell J, Lax S, Bokulich NA, Mills DA, Martin G, Taghavi S, van der Lelie D, Gilbert JA (2015) The soil microbiome influences grapevine-associated microbiota. mBio $6: \mathrm{e} 02527-14$

600

$601 \quad$ Figure captions

602

603 Fig. 1

604 Approaches to study biological control in different trees and woody plants contained in 605 this Special Issue. These studies (reference included) use diverse biocontrol agents 606 (represented by figures of fungi, bacteria, viruses, nematodes) to fight against some 607 major biotic constraints of trees and woody plants. 


\section{Acknowledgments}

We are grateful to two anonymous reviewers for their comments and suggestions to improve an earlier version of the manuscript. Research on Verticillium wilt of olive in Jesús Mercado-Blanco’s lab supported by grants P07-CVI-02624 and P12-AGR-667 (Junta de Andalucía, Spain), AGL2009-07275 (Spanish MICINN/MINECO), and RECUPERA 2020 (MINECO-CSIC agreement), all co-funded by ERDF from EU. Research on bacterial biocontrol of avocado white root rot was supported by grant AGL2014-52518-C2-1-R (Spanish MINECO). 


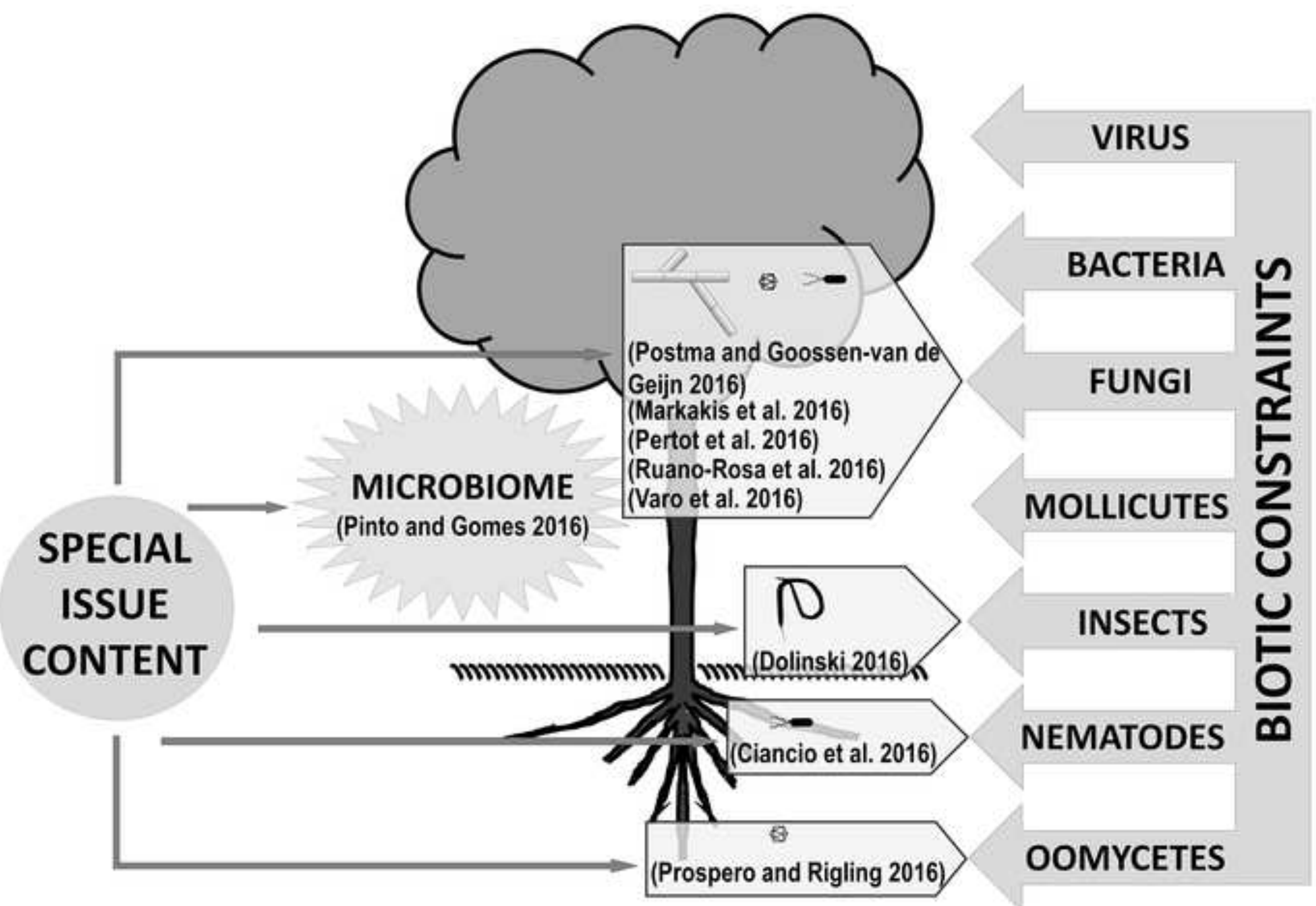

Biocontrol agents: \begin{tabular}{|l|l|l|l|}
\hline$\quad$ Fungi & Virus & - Bacteria & N Nematodes \\
\hline
\end{tabular} 